\title{
Reflexiones en torno a una conciliación: Arquitectura en el territorio peruano en el siglo XVI
}

\author{
Martha Barriga Tello \\ Universidad Nacional Mayor de San Marcos \\ martha_barriga@yahoo.com.ar
}

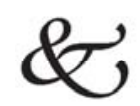

\section{Resumen}

Ante la experiencia con el patrimonio arquitectónico peruano en el siglo XVI, la administración española enfrentó dificultades con las que debió competir con ventaja. Algunos aspectos de nuestra arquitectura religiosa coincidían con sus tradiciones, pero otras de manera ninguna; finalmente hubo consenso. Este artículo es una reflexión acerca de las motivaciones y las consecuencias de este resultado.

Palabras claves: Arquitectura colonial, arquitectura religiosa colonial, patrimonio artístico, siglo XVI.

\begin{abstract}
In the experience of the peruvian heritage the spanish administration in the XVI century found dificulties to compite in advantage. Some aspects of the peruvian religious architecture coincide with their tradition, others not by far, but finally it became a consensus. This article is a reflection about the motivs and the consecuences of that finding.

Keywords: Colonial architecture, religious colonial architecture, Artistic patrimony, XVI century.

$Y$ donde es esta fortaleza [Guarco] y lo que quedado de la del Cuzco, me parece a mi que se debía mandar, so graves penas, que los españoles ni los indios no acabasen de deshacerlas, porque estos dos edificios son los que en todo el Perú parecen fuertes y más de ver, y aun andando los tiempos, podrían aprovechar para algunos efetos (Cieza I, Cap. LXXIII) ${ }^{1}$.
\end{abstract}

1 Pedro Cieza de León es ampliamente explicativo y muestra haber tenido la experiencia de lo que narra, pero Pedro Pizarro como a otros, lo acusa de haber escrito "de oidas, y creo yo muy poco de vista, porque en verdad, yo no le conozco, con ser uno de los primeros que en este 
Las huestes de Francisco Pizarro ingresaron al territorio del Tawantinsuyo en el Perú por la costa, en la que fundaron la primera ciudad, San Miguel, en lo que actualmente es Piura. Transitaron por el Camino Real de los ingas [que] pasa por estos valles entre arboledas y otras frescuras muy alegres (Cieza de León I: Cap. LVIII) (...) un camino tan ancho como quince pies $[4.50 \mathrm{~m}]$, por una parte, y por otra dél iba una pared mayor que un estado bien fuerte; todo el despacio deste camino iba limpio y echado por debajo de arboledas, y destos árboles por muchas partes caian sobre el camino ramos dellos llenos de frutas, y por todas las florestas andaban en los árboles muchos géneros de pájaros y papagayos y otras aves...Por este camino duraban las paredes que iban por una y otra parte dél...[hincados] largos y cumplidos palos, a manera de vigas, de trecho a trecho... de manera que este camino fue gran cosa... (Cieza I: Cap. LX).

El funcionario Agustín de Zárate lo recordó con casi "cuarenta pies de ancho, con muy gruesas tapias del un cabo y del otro, y cuatro o cinco tapias de alto" (Zárate, Tomo II, 138), era el camino Inca de la costa que iba paralelo al de la sierra y a los otros muchos que los conectaban transversalmente. Fue una experiencia que los impresionó y les permitió recorrer todo el territorio.

\section{Establecimiento de los españoles}

Así ingresaron hasta Cajamarca, al norte del Perú. Poco después de ocurridos los sucesos que culminaron con el asesinato del Inca Atahualpa, se iniciaron las acciones de colonización con la fundación de ciudades, entre ellas Cusco en 1533 y Lima en 1535. Muy pronto la corona legisló sobre un fenómeno denunciado por las primeras autoridades americanas, respecto a que “...los españoles que hasta ahora avian ido al Perú como no tenían intención de vivir, y permanecer allí, y si la de conseguir alguna cantidad de oro, y la plata para volverse con ella a estos reynos..." no habían construido casa para su morada ni mostraban interés en propiciar alguna. En

reino entraron", lo que comenta luego de lanzar la acusación que muchos de los testigos de escritores como Cieza luego les habrían pagado para que los incluyese en las narraciones. Cierto que Pedro no estuvo un tiempo en Perú y luego afincó en Arequipa, pero deja sembrada la duda respaldada en haber sido testigo presencial de los hechos (Pedro Pizarro 1968 I:561) 
consecuencia, el 9 de septiembre de 1536 una Real Cédula estableció medidas radicales,

Mando al Gobernador o Juez de Residencia de la Nueva Castilla llamada Perú probeyese luego como cada una de las personas que en aquella provincia tubiesen yndios encomendados edificasen una casa de piedra en el lugar, y parte, y de la manera, forma y traza que le pareciese, para lo cual les señalase los solares que huviesen menester los quales y casas que en ellos se construyesen fuesen propias y como tales pudiesen en cualquier tiempo disponer de ellas en vida, o muerte...

Ante la eventualidad, más que probable, que los colonos se opusiesen a invertir en un lugar de residencia estable, el rey previno

...y si algunos no lo hiciesen ordenase, que de los tributos que rentasen los dichos yndios encomendados se edificase la casa, y hasta concluirla no se las diese con ellos; y no haviendo en la tierra o comarca donde se huviese de construir casa, comodidad de piedra se hiciese de argamasa o tapiería, u otros materiales los más perpetuos que pudiesen ser havidos (Cedulario, tomo 35, fol. 24ํㅡ, no ${ }^{\circ}$ 34).

El gobierno español estaba decidido a sentar plaza en los territorios a través de sus representantes y súbditos pues era indispensable demostrar que había intención de permanecer en condición de dueño y administrador; además la presencia extranjera debía consolidarse enviando un mensaje directo del nuevo orden a las poblaciones nativas. Hacia mediados del siglo XVI en el Cusco los españoles habían encontrado una fórmula cómoda, vivir en casas que según testigos "son las mesmas que los indios tenían, aunque algunas reparadas y otras acrecentadas" (Zárate 1968: II, 134), por ello se negaron al proyecto de trasladar la capital a otra zona de clima más benigno, argumentando muy comprensivamente que, "como haya tan grandes edificios en las casas de sus moradas, no se mudará por no tornar de nuevo a edificar, ni lo permitirán porque no se pierda la antiguiedad de la ciudad" (Cieza I, Cap. XCIV).

Efectivamente, la creación de pueblos y la fundación de ciudades, con frecuencia desplazó a las poblaciones originarias o las reunió en espacios alejados de los que acostumbraban ocupar, para que los españoles pudieran tomar posesión de los sitios e instalaciones que utilizaban, lo que para los habitantes originarios significó un cambio radical de régimen de gobierno y de derechos, así como los obligó a la 
identificación de un orden distinto. Esta modalidad fue coincidente con la que los Incas aplicaban a los pueblos en sus avances de conquista, y con la misma intención de dejar claramente establecido que la autoridad emanaba de sujetos distintos a los que hasta el momento los dirigían. Las comunidades conocían el código y en su mayoría aceptaron la convención pero, como también era parte del sistema, esto no significó reconocerlo permanentemente y sin objeciones.

En este punto debe considerarse dos factores o actores: A)la población originaria y B) la población extranjera. Los peruanos habían desarrollado un imaginario que los identificaba en cada una de las zonas que ocupaban como pueblo. Su imaginario suponía una construcción de identidad y consciencia colectiva resultado de un largo, y muchas veces violento, proceso de configuración como pueblos con sus objetos y materiales simbólicos, entre estos la arquitectura; y en su relación con la administración y la cultura imperial Inca que aunque respetaba las diferencias igualmente defendía que en el contexto globalizado del Tawantinsuyo lo que sostenía el orden era la tradición y el respeto a la autoridad, un proceso que identifica Cornelius Castoriadis como "el repertorio de imágenes vigentes en la consciencia/ inconsciencia colectiva que da coherencia a la sociedad (Alméras 2009). En este contexto se advierte que entre las aspiraciones del segundo componente, el español, se presenta la necesidad de diferenciarse y paralelamente consolidarse como grupo identificable. Pero paralelamente, para la construcción de un nuevo escenario depende del factor nativo. Este factor, sin embargo, tiene sus mismas aspiraciones y defiende sus principios de configuración con el mismo empeño, con mayor vehemencia si lo obligan a convertirse en el verdugo de las objetivaciones de su imaginario colectivo, mancillando su sentido institucional de orden. Para el gobierno español fue necesario establecer el orden urbano con los edificios administrativos, señalar a los residentes con los edificios particulares, y destacar a la religión que respaldaba sus acciones con la construcción de por lo menos un templo y debió enfrentar y conciliar una fórmula de consenso.

\section{La construcción de templos como establecimiento de posesión}

Los españoles tuvieron un proyecto político religioso engranado y que se sostenía mutuamente. Junto con la preocupación por ocupar 
físicamente el espacio seglar, estuvo la de establecer el religioso, y no exclusivamente orientado a convencer a las poblaciones nativas, sino también para salvaguardar su preeminencia en la mente y los objetivos del colonizador. La construcción de iglesias, por precaria que fuera al inicio, estableció esta presencia que se inscribe en una práctica ancestral. El templo, como lugar y edificio sagrado concentra los valores y expresiones vivas de una creencia. Delimitar un espacio con características específicas, identificable con una concepción religiosa, la evoca y la reafirma. En el proceso de colonización los españoles tomaron posesión de los sitios sagrados nativos con la intención de "en su lugar poner la cruz, para poner temor y espanto al demonio, nuestro adversario" (Cieza de León I, Cap. LXXXI). La necesidad de sacralizar el espacio trascendió a los vencidos para enfrentar un mal poderoso y omnisciente, al demonio mismo que, aunque se manifestaba a través de ellos, era un enemigo permanente. Ello condujo acciones precisas que se aplicaron estrictamente.

El templo cristiano tenía entre sus prerrogativas ser lugar de refugio y protección para los fieles, especialmente para aquellos injustamente perseguidos que contaran con el apoyo eclesiástico (el dextrum). Al instituirse en el Perú la condición del edificio religioso y determinadas las pautas de comportamiento los usuarios, fieles españoles e indios recientemente convertidos, participaron de su sacralidad contribuyendo a su construcción, instituyendo capillas particulares, apoyando en su ornamentación con retablos, pinturas, alhajas y, especialmente, solicitando permiso para su enterramiento y el de sus descendientes. El templo así se incorporó a la vida de las comunidades, los pueblos y las ciudades y se ofreció como una divisa de ascenso social, celosamente defendida por los primeros en la tierra y los incas nobles. Coincide en ello la creencia en ambas culturas de que estos recintos debían estar vinculados a quienes tuvieran derechos de sangre para ello. Y si no fuera así, la capacidad económica era excelente justificación para el sustituto.

\section{La iglesia cristiana en Cajamarca y su valor simbólico y formal}

En el Perú, preso el Inca Atahualpa, una de las primeras acciones que realizaron los españoles fue levantar un edificio señalado como iglesia: 
Francisco Pizarro “...mandó hacer en la plaza de Caxamalca una iglesia donde se celebrase el santísimo sacramento de la misa” (Jerez 1968: I, 238), en la que posteriormente velaron al Inca: “... y al otro día de mañana lo enterraron en una yglesia que allí teníamos”. (Mena 1968: I, 100). En este escenario del templo cristiano ¿Cuál su inclusión o rechazo en el imaginario indígena? ¿Cuál en el imaginario del colonizador?

A Pedro Cieza de León le contaron una anécdota singular que debió ser de conocimiento público, en la que Francisco Pizarro ignoró el dextrum, privilegio indiscutible del templo

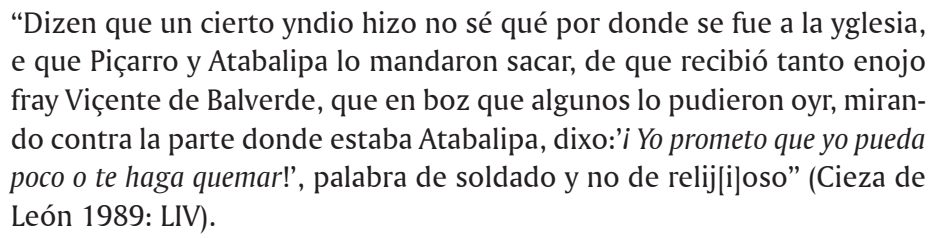

Pizarro desautorizó al dominico, lo que pudo haber alterado su ánimo. El comentario del autor se refiere a que el dominico no se comportaba como religioso, sino como soldado. Este hecho sugiere que el aspecto del templo contribuía significativamente al respeto que despertaba entre los hombres. Un galpón, o una construcción precaria podía, por no ser digna de aquél a quien estaba consagrado, ser insuficiente razón para respaldar su excepcionalidad.

\section{La formalización que enfrentaron los españoles}

La arquitectura peruana antigua fue sobria y continuó siéndolo durante la administración española. Su interés se concentró en la monumentalidad controlada de carácter antropocéntrico y en los revestimientos de oro y plata que constituían tributo a los dioses a través de la presencia del Inca. Garcilaso de la Vega tomó como ejemplo, que extiende a otros templos en el Tawantinsuyo, al Coricancha ("barrio de oro") del Cusco, en el que "el aposento del sol" comprendía lo que en su tiempo era la iglesia de Santo Domingo. En la zona del altar, que estaba situada hacia el oriente, figuraba el dios Sol trabajado en una plancha de oro gruesa "la figura estaba hecha con su rostro en redondo, y con sus rayos y llamas de fuego, todo de una pieza, ni más ni menos que la pintan los pintores. Era tan grande, que tomaba todo el testero 
del templo, de pared a pared"2. Los muros, "todas las cuatro paredes del templo estaban cubiertas de arriba debajo de planchas y tablones de oro". Posteriormente describe que existía en el exterior un jardín de oro y plata, todo "contrahecho al natural" con el metal que se llevaba de ofrenda. Señala que

\begin{abstract}
la puerta principal del templo miraba al norte como hoy está, sin la cual había otras menores para servicio del templo. Todas estas estaban aforradas con planchas de oro en formas de portada. Por defuera del templo, por lo alto de las paredes del templo, corría una cenefa de oro de un tablón de más de una vara de ancho en forma de corona que abrazaba todo el templo. ${ }^{3}$
\end{abstract}

Luego, un patio interior que señala como "claustro" de cuatro lienzos, uno de los cuales era el del templo y que "por todo lo alto del claustro había una cenefa de un tablón de oro de más de una vara en ancho que servía de corona al claustro". Lo interesante es que menciona inmediatamente que "en lugar de ella mandaron poner los españoles en memoria de la pasada otra cenefa blanca de yeso del anchor de la de oro, yo la dejé viva en las paredes que estaban en pie, y no se había derribado". Deberá tenerse en cuenta esta sustitución porque, finalmente, era el contraste entre lo antiguo y lo moderno; entre lo propio y lo extranjero; entre lo verdadero y lo falso, lo que alimentaría el imaginario en construcción del hombre peruano.

Sigue la descripción señalando que el claustro daba acceso a cinco aposentos cuadrangulares grandes. Uno de ellos estaba consagrado a la Luna por lo que las paredes estaban enchapadas en planchas de plata y en una figuraba "hecho y pintado un rostro de mujer [Mamaquilla o Madre Luna] en un tablón de plata" ${ }^{4}$. La sala contigua había sido dedicada a las estrellas, que por estar vinculadas a la Luna figuraban en el techo "sembrado de estrellas grandes y chicas a semejanza del cielo estrellado", trabajadas en plata igual que la cubierta de las paredes y la puerta.

2 Esta es la plancha que él cuenta que tocó a Mancio Serra de Leguizano que la perdió una noche en el juego y al "que yo conocí y dejé vivo cuando me vine a España”, a partir de lo que se acuñó la frase juega el sol antes que amanezca, que menciona Acosta

3 Garcilaso de la Vega, Comentarios Reales de los Incas. Madrid, Biblioteca de Autores Españoles, 1963: Libro Tercero, cap. XX

4 Aunque Garcilaso parece distinguir claramente la pintura de otras técnicas, también aplica el término como equivalente a "representación", por lo cual debe tenerse en cuenta el contexto de cada explicación 
El otro aposento, guarnecido en oro, estaba destinado al "relámpago, trueno y rayo" comprendidos en una única mención como Illapa. Aquí Garcilaso de la Vega hace una interesante acotación,

No dieron estatua ni pintura al trueno, relámpago y rayo, porque no pudiendo retratarlos al natural (que siempre lo procuraban en toda cosa de imágenes) los respetaban con el nombre Illapa, cuya trina significación no han alcanzado hasta ahora los historiadores españoles... Yo escribo, como otras veces he dicho, lo que mamé en la leche y vi y oi a mis mayores" (Garcilaso 1963: Libro 3oo, Cap. XXI).

Aquí el narrador hace tres afirmaciones puntuales que quisiera reseñar, aunque constituyan una digresión. En primer lugar señala que no había representación de Illapa porque su imagen no pudo ser tomada del natural, como acostumbraban hacer. Esto contradice en gran parte la extendida afirmación del carácter abstracto de la plástica Inca, y pudo corresponder a una situación cierta, o ser la respuesta del Inca para oponerse a la percepción española. Si se pensara en una posición de resistencia, que de la Vega no tuvo, podría señalarse que el hecho de enfatizar que no se representaba plásticamente lo que no podía constatarse en la realidad, era una respuesta a la imposición española de que se rindiera culto a imágenes que representaban a personajes no comprobables físicamente ${ }^{5}$. Profundizando en su inicial reivindicación de la condición Inca señala también la concepción de uno y trino de Illapa, un tema que ha sido ampliamente tratado por la historiografía respecto a la representación de la Trinidad que insistieron en usar los peruanos, incluso con apoyo de los religiosos, hasta que fue terminantemente prohibido. Y la tercera es el enfrentar de antemano una posible acusación de falsedad. Insiste en que lo que no le contaron sus mayores, lo "mamó en la leche", una frase que suele utilizarse como máxima prueba de testimonio fehaciente y verdadero. No es que debamos creer siempre lo que afirma, seguramente de buena fe, pero debía haber recibido reproches en este sentido cuando se apresura a insertar la frase

5 Pero no era su intención llegar conscientemente a estos extremos, menos aún cuando a propósito del mismo Coricancha y sus claustros, que menciona enriqueció el Inca Pachacutec enchapando todas las paredes con planchas de oro, señala que en el lugar en el que antiguamente estaba situada la figura del sol, posteriormente con los españoles era más rico "de verdadera riqueza y bienes espirituales que entonces lo estaba de oro y piedras preciosas", porque allí estaba colocado el Santísimo Sacramento en el templo de Santo Domingo. Garcilaso de la Vega, Inca 1963: Libro sexto, cap. XXXII. 
después de describir las maravillas antiguas de su pueblo. Como quiera, no fue el único que mencionó la riqueza extrema encontrada por los españoles, si bien algunos narradores involucrados en el saqueo tienden a narrarlo brevemente pues la mayoría no dio cuenta, ni pagó la tasa correspondiente, pero era de conocimiento general los beneficios que obtuvieron los soldados iniciales y fue el referente que no pudo soslayar la administración posterior, preocupada por equilibrar el prestigio de los signos exteriores.

El 28 de agosto de 1571 el virrey Francisco de Toledo dio unas Disposiciones sobre la construcción de la catedral del Cusco. Calificaba la que existía de "un bohío con mucha indecencia" (131). Como el Cabildo Catedralicio había aducido escasez de fondos, decidió que se redujera el salario de los clérigos doctrineros por seis años (132), y con ello se aplicara a la fábrica y a la compra de ornamentos. Convocó oficiales de todo el reino

$$
\begin{aligned}
& \text { y se trata del precio en que han de hacer y acabar la dicha iglesia y se van } \\
& \text { juntando materiales y se manda hacer de tres naves, con su trascoro y } \\
& \text { portadas y esquinas y pilares de cantería y lo demás todo de ladrillo, en } \\
& \text { que parece vendrá a costar setenta u ochenta mil pesos }{ }^{6} \text {. }
\end{aligned}
$$

Trece meses después no se había avanzado nada de esta propuesta. Entre las Ordenanzas que dio el virrey Francisco de Toledo (1569-1574) en el Cusco (Chacacupe) el 18 de octubre de 1572, recogió la preocupación inicial de la administración española, y suya, para insistir en que la iglesia que entonces existía en el Cusco no era apropiada, a pesar de ser una zona próspera y haber recibido apoyo del monarca

$$
\begin{aligned}
& \text { Item, por cuanto muchas veces ha proveido Su Majestad que las iglesias } \\
& \text { catedrales de estos reinos se edifiquen con la suntuosidad y ornato que } \\
& \text { conviene, para que el culto divino se celebre con la autoridad necesaria, } \\
& \text { porque siendo lo susodicho conveniente en todas partes, mucho más } \\
& \text { obligación es en estas Indias, por ser la gente nuevamente convertida y } \\
& \text { plantas nuevas, para cuya conversión y edificación en las cosas de nuestra } \\
& \text { santa fe católica es menester mucho más cuidado, allende del ejemplo que } \\
& \text { de nuestra parte se les ha de dar en la veneración de las cosas divinas y au- } \\
& \text { toridad en que tenemos las iglesias y casas de religión (...) considerando } \\
& \text { que...[la catedral del Cusco] está al presente como la que al principio } \\
& \text { se fundó, que allende de ser pequeña según la gente del pueblo, el edificio } \\
& \text { es bajo de tierra y muy común para lo que fuera razón, y que habiéndose }
\end{aligned}
$$

6 Francisco de Toledo, Ordenanzas I, Disposiciones...Cuzco, 28 de agosto de 1571: 133. 
tratado tantas veces de fundar y edificar la dicha iglesia se ha gastado ya dicha hacienda sin provecho ninguno, y pareciendo que los medios es la principal parte para que la dicha iglesia se edifique y haya efecto, lo que su Majestad pretende y ha mandado diferentes veces...se concluya la dicha obra considerada la baja que en esta ciudad ha dado todo y la pobreza en que la halló para que...venga a tener efecto la dicha obra con brevedad..." (Toledo, Disposiciones I, Título XXXII:218-220).

Fue más enfático esta vez el virrey, pues tal como demuestra su observación, el edificio era simple y "muy común" considerando la importancia del lugar y la permanente e implícita confrontación con la experiencia indígena en el Tawantinsuyo. Este fue un problema corriente en la época porque, a pesar que los implicados tenían que estar conscientes de esta situación, las primeras edificaciones religiosas españolas en territorio peruano, por su inmediatez y adaptación apresurada, fueron construcciones simples de dimensión modesta, de una sola nave y techo de madera a dos aguas cubierto con paja. Con frecuencia los frailes los reconocieron como inapropiadas al fin que se les tenía destinado, incluso en fecha avanzada. Si consideramos que por lo menos en el primer momento, muchas de las aristocracias étnicas en el Perú apoyaron la toma de posesión del Imperio por los españoles, porque se consideraron partícipes de un proyecto común que tenía como objetivo derrocar el poder Inca, y que esta actitud supuso que pusieran a disposición de los españoles los recursos necesarios para lograrlo, estas primeras construcciones se hicieron con la anuencia y apoyo de los curacas. De acuerdo con los testimonios de las crónicas que describen su aspecto reducido y precario, el templo no fue indicio inmediato de que los extranjeros llegaban convencidos de quedarse y mucho menos tenían un aspecto que compitiera con los edificios Incas. Habiendo transcurrido 34 años desde la entrada de Pizarro en el Cusco se explica que Francisco de Toledo fuera directo en establecer lo que se esperaba de un templo cristiano en estas circunstancias: "Item, que la dicha iglesia sea de tres naves y la capilla mayor sea de bóveda y lo demás de madera, o de bóveda como mejor pareciere, y que no haya otra cosa en la dicha capilla mayor sino un coro, y que se gasten en la dicha iglesia setenta mil pesos ensayados"(Toledo, 1986: Título XXXII). 


\section{Edificios que superaran a los nativos}

Desde muy temprano los europeos en el Tawantinsuyo tuvieron una experiencia directa del mundo representacional que enfrentarían. Francisco de Jerez refiriéndose al tesoro del rescate de Atahualpa, menciona que parte del oro que se transportó a Cajamarca estaba constituido por "planchas a manera de tablas de cajas, de a tres y a cuatro palmos ${ }^{7}$ de largo [entre 63 y $84 \mathrm{~cm}$ ]. Esto quitaron de las paredes de los bohios, y traian agujeros, que parecen haber estado clavadas" (Jerez 1968: 259). Poco después Miguel de Estete, compañero de Hernando Pizarro señaló “...en una provincia cerca del Cuzco se hallaron ciento cincuenta tablas de plata, de quince y veinte pies ${ }^{8}$ de largo [entre 4 y 6 metros], y otras piezas monstruosas echadas por el suelo en una bóveda casi anegada de tierra"(Estete 1968: 398). Pedro Pizarro, también Secretario de Francisco, mencionó el informe de un indio "que detrás de la fortaleza del Cuzco, en el llano, había una bóveda muy grande de debajo de la tierra donde había más de cuatro mil cargas de oro y plata que estaba allí enterrada y escondida" aparentemente destinadas a enchapar la casa de Huayna Capac, tesoro que jamás fue localizado por haber sido asesinados todos los testigos (Pedro Pizarro I: 501-502). Planchas como las mencionadas formaron parte del ornamento murario de los templos y casa principales, fueron vistas por los soldados y religiosos, por lo que debieron constituir referente necesario para el plan constructivo que debía iniciarse.

Conforme fue llegando un mayor número de representantes de las diversas órdenes religiosas se decidió afianzar su poder en los territorios asignados, reemplazando los iniciales por otros templos, más a propósito con el objetivo de la campaña, para lo que recurrieron a la mano de obra indígena y la utilización de los recursos comunales, lo que fue el origen de un malentendido de dimensiones colosales. Hacia 1541, en una carta del Provincial Luis de Morales al rey se conoce que se construía, con el apoyo de los indígenas y con el respaldo de las autoridades españolas (Lisson Chávez 1943: v. 1, № 3,67). El 2 se septiembre de 1542 el Cabildo de la ciudad de Huamanga en Ayacucho,

7 palmo: equivalente a $021 \mathrm{~cm}$

8 pie: equivalente a $030 \mathrm{~cm}$ 
aprovechando la visita y el ofrecimiento del Provincial de los dominicos fray Tomás de San Martín, decidió que le fueran entregados cuatro solares a su elección, para edificar la iglesia y convento de su Orden en la ciudad. A propósito de ello

les señalaban y señalaron para la obra del dicho monasterio toda la piedra del edificio y fortaleza que está hecha junto a esta dicha villa en cierta tierra de Martín de Anduela; los cuales dichos cuatro solares le señalaban como sea sin perjuicio (Libro de Cabildo de la Ciudad de San Juan de la Frontera de Huamanga. 1539-1547. Descrifrado por Raúl Rivera Serna, Lima, Casa de la Cultura del Perú, 1966: 97. Gonzáles 1997: 174)

La práctica de reutilizar oficialmente el material de los edificios Incas se mantuvo durante todo el virreinato. El 1720 fue permitido que se retiraran piezas de la fortaleza de Sacsayhuamán (Cusco) para construir el Hospital de los naturales de San Pedro ${ }^{9}$, y los mismos indios utilizaron materiales tomados de templos y fortalezas, a pesar de las prohibiciones. Cuando se abolió el servicio personal de los indios regresaron a sus comunidades y, en una comunicación del obispo Juan Solano al rey el 10 de marzo de 1544, cuenta que fue testigo de la decisión de los curacas de "sacrificallos porque eran cristianos y habían servido a cristianos y esto era muy público por los caminos. Y de un cacique yo soy testigo, porque se lo reñí...”. (Vargas Ugarte 1953: I, 252) Las elites indígenas, cambiando de opinión, ahora castigaban a quienes habían cumplido sus órdenes. La reacción se extendió a que "entrasen en las iglesias". (Millones 1984: 9) Tiempo después, desde Vilcas, los sacerdotes incas dieron

un pregón en aquella provincia, para que todos los indios que adorasen lo que los cristianos adoraban, y tuviesen cruces, rosarios, imágenes y vestidos de los españoles habían de perecer en la enfermedad de pestilencia que la huaca enviaba, en castigo de que se habían hecho cristianos; la cual voz recibieron con tanto afecto y determinación que echaron de sí todo lo sobredicho, arrojando en los caminos y quebradas todas las cruces, rosarios e imágenes, sombreros, zapatos, calzones y todas las demás cosas, con los vestidos, que los españoles tenían. Hubo indio que, cuando pasaba por la cruz, volvía la cabeza por no verla ni quitarle(se) el llauto que en ella trae que es su sombrero, ni querían entrar en la iglesia, los miserables... (Vega 1948: cap. IV).

9 Archivo Departamental del Cusco, 1720. Protocolo 61/313, escribano Matías Jiménez de Ortega, fol. 149 "Concierto de sacar piedras de Sacsayhuamán”. Cummins, Brindis con el Inca:. Nota 545 , p. 309 
El recinto religioso era interpretado como receptáculo de la divinidad entre ambos grupos tal como se advierte en la preocupación del clero español por erigir "verdaderos" templos, más acordes a su experiencia y costumbre. En el caso del Perú en la Iglesia primó la evangelización tanto como el que los cristianos conservaran su fe. En ambos extremos fue necesario contrarrestar la calidad y magnificencia de la arquitectura religiosa que encontraban los españoles en el amplio territorio del Imperio, la que, por otra parte, igualmente rememoraba las convicciones intrínsecas del credo nativo. El informe del jesuita Antonio de Vega del Coricancha sobre la base de testimonios directos españoles e indígenas, consigna,

[Coricancha] donde estuvo ...el principal ídolo ....llamado el Punchau... el señor del día, y el hacedor de la luz y del sol, y estrellas y de todas las cosas ...[tenía]...entradas y capillas de admirable labor y fábrica, y como me he informado ... por todo este templo y sus capillas estaba gran suma de piezas de oro y plata, para atavío y adorno del dicho templo, y mayor veneración del Idolo Punchau, y particularmente en los encajes o altares del Templo y capillas que eran de maravillosa arquitectura, estaban asentados muchos bultos, o ídolos de oro y plata y piedra labrada, de varias formas y figuras, de sierpes, o culebras, cóndores,...y de otras diferentes figuras, especialmente en forma humana ...Punchao...era de oro finísimo fabricado en figura humana en forma de Inca, estaba asentado en una silla, o sitial,...toda de oro sólido y finísimo horadadas las orejas y en ellas los orejones o zarcillos, que hasta hoy día vemos ... por las espaldas y hombros le salían unos Rayos de oro macizo (...)Tenía el Idolo a los dos costados, como en guarda y defensa, dos Sierpes de oro... y dos leones bien formados, también de oro y de todo este notable aparato, duran hasta hoy día algunas reliquias. (Antonio de la Vega SJ 1948: Cap.I) ${ }^{10}$

Y es que el "Curicanche" fue un templo mencionado como "de los ricos de oro y plata que hubo en muchas partes del mundo" (Cieza I: XCII) pues en el Cusco

son muchos los edificios que hay, de aposentos y depósitos que hubo, todos de la traza y compostura que tenían los demás en todo el reino; y aunque unos mayores y otros menores y unos más fuertes que otros. Y como estos ingas fueron tan ricos y poderosos, algunos destos edificios eran dorados y otros estaban adornados con planchas de oro" (Cieza I: XCIII)

10 Haciendo un recuento de las características resaltadas en la cita, puede observarse la coincidencia con las imágenes del Niño Manuelito que contó desde el virreinato con la devoción profunda de los pueblos indígenas 
Cieza terminó la primera parte de su Crónica en septiembre de 1550 estando en Lima, por lo que para la Iglesia de España en el Perú este fue el modelo, aún vivo en el recuerdo de los testigos ya fuera que escribieran de inmediato; pocos años después de la conquista, como Cieza; o setenta años después como el jesuita de Vega. El esfuerzo que se desplegó, en tanto se estabilizaba el país, se orientó a contrarrestar los efectos que, incluso entre los españoles, causó la experiencia del esplendor del arte del Imperio. Sin embargo no hubo una respuesta política a la experiencia. No se analizaron las manifestaciones plásticas ni arquitectónicas o urbanas de la cultura nativa para aplicarlas a la configuración arquitectónica religiosa que se deseaba implantar, para organizarla de acuerdo a los requerimientos que se adecuaran a las comunidades y así efectivizar la evangelización, aunque sin embargo los resultados muestran coherencia.

En los Comentarios Reales, Garcilaso de la Vega hizo una acotación respecto a soluciones urbanas, que grafica el problema,

Los españoles, como extranjeros, no han hecho caso de semejantes grandezas, ni para sustentarlas, ni para estimarlas, ni aun para haber hecho mención de ellas en sus historias; parece que a sabiendas o con sobra de descuido, que es lo mas cierto, han permitido que se pierdan todas (Comentarios Reales. Libro Quinto, Cap. XXIV).

Los españoles parecieron ignorar las bondades de los recursos Incas, a pesar que de mantenerlos hubiese solucionado sus propios problemas de gestión. La necesidad de ocultar estos logros en todos los ámbitos, solamente puede interpretarse como la incapacidad para mantenerlos y superar sus beneficios ante una población atenta, así como por la negligencia que mostraron desde que llegaron. En consecuencia, los patrones constructivos en el Perú respondieron en general a la tradición europea adecuadas a la disposición de materiales y al medio geográfico en el que se aplicaron.

Pero, ¿es exacto que los extranjeros fueron ajenos a la experiencia reciente en el Perú? Era práctica aceptada: "Que se fabrique el templo principal en el sitio, y disposición que se ordena (...) En alto para que resalte" (Recopilación 1681: Libro IV, Título VII, Ley VIII,91), o en su defecto, con una escalera frontal que condujera a él, de manera que dominara el lugar en el que se edificaba. La pauta fue seguida por los 
primeros religiosos en el Perú y otros lugares de América, al punto que, salvo las raras excepciones en las que parte del muro del templo prehispánico subsiste, no quedó rastro del mismo. Esta práctica, intrínsecamente con el mismo objetivo aunque respondió a soluciones más prácticas para resolver un problema legal de interés general, se extendió al marco urbano: “... las casas y edificios en que hoy viven los cristianos son las mesmas que los indios tenían, aunque algunas reparadas y otras acrescentadas". (Zárate, 1968:134). La nueva construcción comprometió la previa, la incorporó y adaptó, no siempre la rechazó y eliminó sistemáticamente.

Lo que más preocupó a la institución eclesiástica, tal como se deduce de la carta del Provincial Luis de Morales de 1541, fue el que se desautorizase su poder y, con él, todo el programa evangelizador

Acontece cada día haber mil pasiones y escándalos y otras malas crianzas contra la iglesia, e como los indios naturales ven que quebrantan e fuerzan a la casa de la Santa María con lanzas y espadas y rodelas y otras armas e hazen otros agravios, escandalízanse e tienen por burla a la casa de Santa maría, la cual nosotros les publicamos que no ay otra cosa ni otra señora en el mundo y es harto perjuicio e ynconveniente para la conversión (Lisson Chávez 1943: V. I, №3, 94-95).

Pioneramente, Francisco Pizarro quebrantó el dextrum en Cajamarca a solicitud de Atahualpa (Cieza de León 1989: Cap. LIV), una actitud insólita e impertinente en el momento histórico. Con mayor razón debió entender Valverde y quienes llegaron después, que el objetivo no sería solamente el indígena y que la labor debía extenderse a los españoles también. El Primer Concilio Limense (1551-1552), en las constituciones para los naturales aprobadas el 23 de enero de 1552, reconoció el valor arquitectónico de la edificación originaria cuando estipuló que, encontrados los adoratorios en los pueblos: "sean quemados y derrocados; y si fuere lugar decente para ellos se edifique allí iglesia, o a lo menos se ponga una cruz" (Vargas Ugarte 1951: I, 8), esto último era pertinente especialmente para los lugares venerados por las comunidades. Con ello asumían la preocupación del arzobispo Loaysa (Instrucciones de 1545), respecto a superponer el símbolo cristiano de la cruz al otro, representado por las ruinas del templo nativo, para exorcizar el espacio y sacralizarlo. Ningún lugar era menor para emprender la campaña, desde los 
primeros años del asentamiento español se encuentran disposiciones en las que el tema principal se refiere a que: "en los lugares pequeñuelos también se hagan sus yglesias pequeñas, donde se baptisen y se junten a la doctrina" (Trujillo 1981: 326). O que, en su defecto, se hiciesen adaptaciones del edificio prexistente, una medida que buscó consolidar el discurso evangelizador en los edificios.

El templo cristiano competía en desventaja frente a la reciente experiencia nativa y española del esplendor del Imperio. No podía equipararse el sentido simbólico trascendente que la cultura tradicional otorgaba al oro, ni competir con su valor económico real.

Con planchas de oro chaparon los templos del sol y los aposentos reales, donde quiera que los había; pusieron muchas figuras de hombres y mujeres, y de aves del aire y del agua, y de animales bravos, como tigres, osos, leones, zorras, perros y gatos cervales, venados, huanacus y vicuñas, y de las ovejas domésticas, todo de oro y plata vaciado al natural en su figura y tamaño, y los ponían por las paredes, en los vacíos y concavidades, que yendo lbrándolos dejaban para aquel efecto (Garcilaso 1993: Libro $6^{\circ}$, cap. $1^{\circ}$ ).

Garcilaso se sustenta en autoridad y para ello apela a Pedro Cieza de León (I: Cap. XLIV), pero es obvio que pecó de entusiasmo, por lo menos al referirse a las especies zoológicas que menciona representadas.

\section{Algunas aproximaciones conceptuales y formales}

\section{Riqueza}

Para los casos en los que la referencia era la arquitectura construida en piedra, sustituir la magnitud de su aplicación muraria y escultórica era complicado. Al enchapado en oro de los muros se correspondía la construcción de los paramentos. El diseño arquitectónico Inca y de las otras culturas, escasamente referencial en los restos arqueológicos que podía observarse años después, y su estructura misma, dan cuenta de la solidez y el preciosismo con el que fueron trabajados, además de que respondían a un objetivo estético preciso, correspondiente a la nación creadora. La edificación cristiana puesta en comparación, ejemplificada con el friso en yeso que sustituyó la banda de oro en el Coricancha, a pesar de la riqueza y creatividad de su ornamentación, debió advertirse inconsistente y precaria, como para lograr sustituir a la propia de los 
indígenas, un problema que no se presentó en la costa porque por la calidad de los materiales no lograron soportar el descuido y fácilmente fueron sustituidos por los equivalentes españoles.

Sin embargo hubo aspectos coincidentes. El oro como material incorrupto y eterno fue usado largamente en la tradición judeo cristiana, por lo que no significó un elemento exótico en el imaginario de la Iglesia de España en el Perú, y pudo compatibilizar así como justificar su uso, el que hubiese sido empleado en el Tawantinsuyo destinado a la divinidad y al Inca que la representaba; un material que era entregado como obsequio del más alto honor y que con la plata conllevaba cualidades connotativas de reconocimiento al valor y el servicio de los dioses y del Inca. El templo cristiano mantuvo la sencillez y sus líneas controladas, pero los muros, cubiertas, mobiliario se llenaron de luz áurea y argentaria, que formaba parte de la tradición ancestral cristiana y continuó en el virreinato. Los españoles habían recolectado exvotos de los templos peruanos, retirado enchapes de oro y plata de los muros y recogieron cuanto mueble y objeto de metal precioso encontraron. Para la zona del valle del Colca Juan de Ulloa Mogollón menciona que

\begin{abstract}
Solían tener a cargo las doctrinas destos pueblos de los Collaguas los frailes de San Francisco, donde residían ocho frailes y un guardián; éstos fundaron las iglesias que hay en toda esta provincia y las adornaron de ornamentos y cosas de culto divino con gran curiosidad, de la plata e oro que hallaron en las guacas o cerros nevados e adoratorios antiguos, donde fueron a deshacerlos con gran caridad y fervor (Ulloa Mogollón 1965: 332).
\end{abstract}

Si había que competir, no había mejor interlocutor que el esplendor ornamental evocativo de una deidad superior con un valor simbólico definido, imperecedero, perfecto, incorruptible e inicialmente sin otro valor para el indígena que el del respeto a sus dioses y a su rey.

\title{
Monumentalidad
}

Puede observarse una interesante tendencia constructiva hispana, especialmente en el territorio andino. Tomando como ejemplo la zona del valle del Colca, en Arequipa, por constituir zona relativamente periférica de un centro urbano, y por lo tanto no presionada por un entorno excesivamente competitivo, se encuentra algunos aspectos que destacar. La equivalencia con la arquitectura local se buscó en la sólida 
estructura de los edificios, la organización parietal y la tendencia monumental de los templos, que sobresalen nítidamente en el conjunto del poblado, a pesar que muchas veces su magnificencia no condice con las necesidades locales, pues superan largamente. La mayoría se construyó en un lugar alto dominando un espacio amplio para el atrio cementerio y colindante con la plaza mayor del pueblo, por lo que también tienen escalinatas de acceso. Mantienen la preeminencia de la portada de los pies aunque la posición general del templo fuera perpendicular a la plaza. En sus estudios Ramón Gutiérrez, Cristina Esteras y Alejandro Málaga (1986:93), suponen que esta peculiar ubicación es consecuencia de estar emplazados sobre una construcción religiosa indígena. Los templos presentan sólidos muros de sillar; amplios imafrontes flanqueados por anchas torres de corte cuadrangular; los muros laterales están reforzados con contrafuertes y tienen coro alto en la zona de los pies. La profundidad del muro da lugar a vanos profundos. Son edificios de una sola nave cubiertos con estructuras de par y nudo, salvo el templo de Lari que tiene bóveda de cañón y cúpula, la única en la zona. En general permiten sostener que lejos de existir contradicción entre majestuosidad de la construcción e importancia del pueblo lo que se buscaba era anteponer el discurso de la ocupación en igualdad de condiciones que la construcción local nativa. Los templos son imponentes y destacan nítidamente en un paisaje desolado, poco poblado y de horizontes amplios. Cuando llegaron los españoles la zona era rica en recursos y habilidad agrícola y existían construcciones incas importantes, una de las que estaba cubierta totalmente con planchas de bronce. Este material fue entregado en parte a Gonzalo Pizarro para las herraduras de los caballos; parte fue posteriormente entregado para fundir 4 campanas, y aún restó otra porción sin utilizarse.

\section{Orientación al este}

Otra de las compatibilidades se encuentra el relacionada a uno de los preceptos arquitectónicos que condujo la construcción de templos, la de orientarlos hacia el sol levante. La tradición cristiana de privilegiar el Este no era ajena al mundo peruano antiguo, tal como observaron los cronistas respecto a las tumbas sur andinas, "tan grandes como 
torres, unas más y en otras menos, y algunas hechas de buena labor, con piedras excelentes y tienen sus puertas que salen al nacimiento del sol"(Cieza de León 1947: Cap. LXIII y XLIII). La tendencia de construir templos o sepulcros encarados al Este correspondió a una simbología vinculada a la creencia en la vida perecedera y al reconocimiento del sol como deidad fuente de vida, que encontramos en las tradiciones más antiguas de la humanidad, tanto como en la peruana.

\section{Incompatibilidades}

\section{Atrio cementerio}

Un uso en el que discreparon ambas culturas fue el que estuvo asociado a la costumbre cristiana del enterramiento en el atrio de los templos, lo que en los primeros tiempos de la Iglesia comprometió también el interior. En el siglo XVI se continuaba con la práctica medieval de reservar lugares de privilegio a familias principales al interior del edificio, pero el atrio se mantenía como cementerio común. En el Perú la administración eclesiástica intentó establecer que los difuntos recibieran sepultura en los atrios en tanto lugares destinados para cementerio, considerándolos privilegiados por su proximidad al templo sagrado. Los indígenas reaccionaron ante esta normativa que se oponía a las suyas, en las que estaba implícito que no compartían tampoco la consideración sagrada del lugar. El que les correspondía por tradición era el próximo a los cerros. Adicionalmente, es comprensible la actitud si recordamos que para los peruanos los difuntos seguían participando de sus vidas. Mantener el nexo con los seres queridos brindaba protección, una profunda vinculación y estrechamiento de los lazos familiares, eje de la sociedad y garantía de supervivencia de la cultura. Hacia finales del siglo XVI José de Acosta afirmó que muchos de los indios: "desentierran secretamente sus difuntos de las iglesias y cementerios y los entierran en cerros o quebradas o en sus propias casas" (Acosta 1954: Parte V, Cap. VII; Barriga Tello 2007), acompañados de sus ceremonias. El Segundo Concilio Limense (1567), entre otras disposiciones contrarias a estas y otras costumbres indígenas, prohibió los ritos tradicionales que precedían las actividades vinculadas a los entierros, (Trujillo 1981: 329). 
El hallazgo de la tumba del Inca Paullo Topa en el Cusco, organizada respetando el ritual de sus ancestros aunque al pie del altar mayor de la iglesia de San Cristóbal representó, como señala la investigadora María del Carmen Martín Rubio "un fuerte gol a la Iglesia de su tiempo: así demostró el total rechazo que sentía hacia la presencia extranjera y su cultura” (Martín Rubio 2008: 61; “Evaluarán...2007), con mayor impacto porque Paullo era considerado por la historiografía un traidor confeso a la causa inca y un renegado de su raza (Dunbar Temple, 2009). Otro hecho revelador próximo a finalizar el siglo XX, fue protagonizado por los comuneros de Caramia (Yauyos, Lima) cuando, desde aproximadamente 1985, comenzaron a desenterrar momias de las ruinas pre Incas de Huamanmarca, llevándolas a sus casas para rendirles culto. Según afirmó una testigo "los comuneros han convertido las momias en objeto de adoración”, ( $E l$ Comercio 1987: 5 octubre).

\section{Concepción del espacio}

Otro aspecto que se incluye en este rubro es el de la concepción del espacio. Si bien se encuentra variaciones regionales hay marcos comunes que merece señalarse. La caja muraria hispana es simple, longitudinal. El espacio cerrado de los templos iniciales de una nave y cubierta a dos aguas de par y nudo es contenido, limitado y controlado. Los retablos laterales de madera o de estuco, así como los trabajados en nichos tipo arcosolio, o algunos de los anteriores al interior de éstos, tienden a separar y a jerarquizar el espacio del muro.

El templo no se expande en altura y pronto la nave única dará lugar a espacios abiertos en los laterales para capillas particulares, que no distraían la atención porque se aislaban con rejas de manera que el ábside mantuvo su preeminencia axial así como las columnas, frecuentemente de amplio diámetro y poca altura, orientaban el ritmo del desplazamiento hacia el altar. Salvo que no se decidiera quebrar la continuidad de la nave central colocando el coro cerca de su último tramo, próximo al presbiterio. En ese caso el desplazamiento aprovechó el descanso del ambón en cuyo cuerpo murario se colocó un retablo para obligar el recorrido hacia ambos laterales. 
El ancho y el alto del conjunto espacial se complementan sin destacar ninguno, lo que no sucede entre sustento y cierre o entre elementos verticales y horizontales. Una moldura o trozo de entablamento marca la vertical respecto a la horizontal de la cubierta, incluso con una pequeña balaustrada de coronación que le resta dureza a la vez que define y delimita claramente los espacios.

El espacio interior del edificio vuelve sobre sí mismo lo que permite una visualidad magnífica, pero controlada de acuerdo a la escala humana. Los muros ocupan gran parte de la diferencia entre interior y exterior del edificio por la necesidad de robustecerlos y afianzarlos ante la posibilidad de los desastres telúricos. Su volumen queda evidenciado en las ventanas profundas trabajadas en ocasiones como arcos enviajados o abocinados que reducen la posibilidad de arcos marcados o toscos. La nave central única en el siglo XVI se separa del amplio presbiterio por arcos de triunfo que marcan la zona de ingreso al ábside que generalmente es plano y está totalmente ocupado por el retablo mayor. Si no hay coro central, se forma la cruz real con un transepto o virtual por un pequeño reborde en el muro que alude a un transepto, o con un elemento mueble a cada lado que define el travesaño de la cruz sin mostrarlo, una cruz latina virtual o simbólica. Los templos de una nave prevalecen en las doctrinas o reducciones de poca población; los más importantes suelen optar por amplios espacios internos y en ambos casos con capillas abiertas hacia un amplio atrio.

En las ciudades importantes como Lima, Cusco, Arequipa, Trujillo entre otras, los colonizadores buscaron tener espacios señalados para sus capillas particulares, lo que ocasionó que templos construidos inicialmente de una sola nave fueran demolidos para atender las demandas de los conquistadores, convertidos en la nobleza de la tierra. Santo Domingo, iniciado en 1539 en Lima debió demolerse en 1540 para cambiar su orientación, así como destinar capillas a sus promotores más importantes. Inicialmente las cubiertas fueron de madera de par y nudo y harneruelo o con vigas corridas. Las crónicas comentan los bellos alfarjes e ingeniosos entrelazos y artesonados. En general el templo peruano es estructuralmente fuerte pero sencillo, de líneas severas y simples al exterior. En la zona sur andina se aplican contrafuertes de piedra que siguen la ordenación de la mampostería incaica sobre cuya 
estructura descansó posteriormente la cúpula ya fuera sobre tambor, o directamente sobre el anillo. El espacio interior del templo se articula flexiblemente entre soportes verticales convenientemente distanciados para mantener la sensación de espacio abierto y fluido.

La concepción espacial andina supuso espacios controlados y continuos como plazas y edificios compartimentados en habitaciones comunicadas visualmente a través de vanos que en ocasiones se suceden en continuidad. Ese espacio, a pesar de la monumentalidad del conjunto, no se muestra agresivo sino que mantiene la vinculación antropocéntrica. Del mismo modo se busca armonizar con el ambiente en el que el edificio se levanta. Los espacios separados se organizan, en general, de manera regulada alrededor de los espacios abiertos. Aunque de acuerdo a las fuentes, la mayor parte de los templos incas "están deshechos y ruinados de tal manera que lo principal de los edificios falta" (Cieza I, Cap. LXXII; LXXVII), aún así fueron referencia en la memoria colectiva y en especial en el recuerdo de Garcilaso de la Vega, que alcanzó a recorrer los del Cusco.

Desde el primer Concilio Limense (1551-1552), se advierte la preocupación española por contar con edificaciones adecuadas al propósito evangelizador, que rivalizaran con la religión expresada en la arquitectura y la ornamentación de las edificaciones del Tawantinsuyo. La Iglesia y el Estado fueron socios en este proyecto que no siempre obtuvo el resultado previsto. Frente a esta concepción estructural y espacial los templos y edificios incaicos presentan en la costa formaciones piramidales y en los Andes espacios con habitaciones continuas organizados sobre la base de grandes patios o plazas. Lo que resalta en los restos que han perdurado es la solidez de los muros y la simplicidad de la organización interna, severa y precisa articulada por pasadizos. Es poco lo que resta como para poder establecer una comparación puntual entre ambas concepciones arquitectónicas, pero lo que se observa es que los europeos tendieron a mantener el sentido del conjunto arquitectónico, su monumentalidad, solidez, grandes paños de muro organizados en formas geométricas con mampostería trabajada y pulida. 


\section{La construcción hispana y los convencidos: una reflexión}

La historia del arte como disciplina integradora, pretende comprender los procesos que conducen los fenómenos creativos y acercarse a la razón del camino que siguen sus concretizaciones. Una lectura antropológica de las acciones señaladas anteriormente, que sirven para explicar el proceso de los componentes referidos al arte vinculados al templo cristiano, se sustentan en la necesidad de la naturaleza humana y de las sociedades que forma, en encontrar un punto armónico que permita a los protagonistas de hechos violentos continuar con lo cotidiano. En el Cusco, por ejemplo, pero no exclusivamente, la construcción de templos y edificios tanto civiles como religiosos, superponiendo construcciones Incas tuvo, como ha sido ampliamente señalado, la intención de establecer las jerarquías del gobierno que se iniciaba. Pero también los pueblos adoptaron el templo cristiano, lo construyeron, adornaron y contribuyeron a su prestancia y terminaron por asimilarlo a su propia tradición. Paralelamente, supuso la respuesta a una condición atávica de enfrentamiento entre grupos adversarios, que dejó un sustrato de violencia no resuelta en los protagonistas.

La ocupación española del Tawantinsuyo fue un proceso violento de abuso y maltrato. La reacción de los vencidos fue inicialmente de rebeldía, la mayor parte de las ocasiones poco organizada y menos exitosa. Entre los vencidos, como era inevitable, los sentimientos de venganza se mantuvieron latentes, y brotaron de manera periódica en gestos y acciones que narran los documentos del siglo XVI. Una generalizada fue el encubrimiento y engaño sordo y disimulado respecto a las riquezas ansiadas por los extranjeros; otra radical fueron los casos del sitio del Cusco en 1533 y el de Lima que mantuvieron en zozobra a los españoles por los siguientes dos siglos, seguros que los indios retomarían el poder en cualquier momento. Por tanto fue evidente para los vencedores, incluso sin ser conscientes de ello, que eran necesarios actos simbólicos compensatorios de sacrificio y expiación que calmara la tensión entre nativos y extranjeros y permitiera continuar.

La agresión española impuso patrones de tortura psicológica al vencido. Los edificios que fueron construidos superponiéndolos a los originarios eran comprobaciones de violencia a la que habían sido y 
eran sometidos sus constructores, a quienes se les obligó a levantarlos, desmontarlos o destruirlos, acción que debió significar para los peruanos un acto de autoinmolación cuya radicalidad fue el extremo de la agresión. Un primer elemento que se ofreció inicialmente que pudo ser considerado como un gesto de conciliación fue el sacrificio de Cristo como redentor, compensatorio del dolor infringido, pretendiéndolo equivalente; pero ese sacrificio era redivivo diariamente en la Eucaristía y pronto debió perder su fuerza significativa como equilibrio al sacrificio indígena. El templo cristiano, destructor del santuario o signo de gobierno indígena, se erigió en reemplazo de la víctima enmascarando su agresión, un gesto que puede interpretarse diferente en los casos en que se privilegió las capillas abiertas porque allí la iglesia se constituía en una gran escenografía para enmarcar la representación del vencedor, con el indígena como espectador externo. De alguna manera los españoles americanos también aceptaron y asimilaron la forma resultante, pero a partir de una apropiación excluyente. El templo cristiano, destructor del santuario indígena, se erige en reemplazo de su víctima y convierte a sus antiguos dueños en verdugos.

Los indígenas, sin embargo, hicieron suya esta acción, se "apropiaron" de los elementos decorativos, de las imágenes, las representaron más cercanas a sus propios rasgos, de manera que la inmolación les perteneció, los representó a ellos mismos y pudo compensar un dolor recurrente y permanentemente revitalizado. De esta manera el templo fue una retribución compensatoria para el pueblo sojuzgado, y las imágenes de dolor que lo poblaron, aquellas que eran más caras a las poblaciones, equipararon el dolor por la propia pérdida.

\section{Conclusiones}

El mensaje ideológico cristiano en el Perú se propagó tanto a través de la disposición arquitectónica como de las artes plásticas. Las estrictas reglas constructivas en algunos aspectos coincidieron con la normatividad del Perú antiguo, en otros casos fueron opuestas, pero se observa la intención española de corresponder sus edificaciones a los principios que encontraron regían las construcciones oficiales en el Tawantinsuyo. La arquitectura fue considerada el marco adecuado al 
propósito evangelizador, a pesar que su disposición no fue ajustada a los requerimientos espirituales de la comunidad indígena, con la que con frecuencia estuvo en conflicto. Los ornamentos que se colocaron en los templos tenían valores simbólicos que reafirmaban los preceptos de la fe cristiana en correspondencia con el edificio en el que se albergaban, relación que también fue en principio ajena a la cultura en la que se pretendían imponer. Paralelamente, durante el siglo XVI el enfrentamiento entre sacerdotes cristianos y nativos fue continuo para atraer a los fieles a sus respectivos ritos, en una confrontación que no detuvo el curso de los acontecimientos. El virreinato se cubrió de templos cuya tipología evidencia a los protagonistas. A pesar que los desastres sísmicos obligó a reconstruirlos varias veces, los nuevos edificios retomaban la tendencia anterior aunque sus rasgos se adecuaran a la moda de la época. Quedan pocos edificios del siglo XVI, pero son suficientes como reflejo de un lento y continuo proceso creativo de adaptación.

\section{Referencias bibliográficas}

ACOSTA S.J., José de (1954): Historia natural y moral de la Indias. Madrid: Biblioteca de Autores Cristianos, № 73, (5-388).

ALMÉRAS, Diane (2008): Lecturas en torno al concepto de imaginario. Apuntes teóricos sobre el aporte de la memoria a la construcción social. http://www.uchile.cl/facultades/filosofia/publicaciones/cyber19/ almeras.htlm.

ARCHIVO DE LA HISPANIC SOCIETY OF AMERICA (AHSA) Las leyes y premáticas reales hechas por sus magestades en las cortes que mandaron hacer e hicieron en la ciudad de Toledo. En las cuales hay muchas leyes y deficiones nuevas y aprovación y declaración de muchas premáticas $y$ leyes del Reyno: fin las cuales ningun adminiftrador de justicia deve estar. Toledo,1525. Salamanca, Casa de Juan de Junta, 1550

BARRIGA TELLO, Martha (2007): "Denunciar y convencer. Un problema textual en una crónica del siglo XVl", en: Nuevas cartografías literarias en América Latina. Entre la voz y la letra. Biagio D’Angelo (organizador), Lima: Asociación Peruana de Literatura Comparada (ASPLIC), Asociación Internacional de Literatura Comparada, Fondo Editorial de la Universidad Católica Sedes Sapientiae. 
CIEZA DE LEÓN, Pedro(1947): La crónica del Perú. Primera parte, Madrid: Biblioteca de Autores Españoles, T. XXVI.

CIEZA DE LEÓN, Pedro(1989): La crónica del Perú. Tercera parte, Lima: Fondo Editorial de la Pontificia Universidad Católica del Perú y Academia Nacional de la Historia.

CUMMINS, Thomas (2004): Brindis con el Inca, Lima: Fondo Editorial de la Universidad Nacional Mayor de San Marcos, Embajada de USA y Universidad Mayor de San Andrés.

DUNBAR TEMPLE, Ella (2009): La descendencia de Huayna Cápac, Lima: Fondo Editorial de la Universidad Nacional Mayor de San Marcos.

Estatuto de la Organización de las Iglesias en Indias firmado por Felipe II en 1563, en: ARRAGARAY Apéndice del Cap. IV: Documento del Archivo de la Embajada de España: Título IX: De las Iglesias.

ESTETE, Miguel de (1968): Noticias del Perú de .... Lima: Editores Técnicos Asociados, Biblioteca Peruana, I.

GARCILASO DE LA VEGA, Inca (1963): Comentarios Reales de los Incas, Madrid: Biblioteca de Autores Españoles.

GONZÁLES CARRÉ, Enrique (1997): Ayacucho, San Juan de la Frontera de Huamanga. Lima: Banco de Crédito del Perú.

GUTIERREZ, Ramón; ESTERAS, Cristina y MÁLAGA, Alejandro (1986): El valle del Colca, (Arequipa). Cinco siglos de arquitectura y urbanismo, Buenos Aires: Instituto Argentino de Investigaciones de Historia de la Arquitectura y del Urbanismo.

JERÉZ, Francisco de (1968): Verdadera relación de la conquista de la Nueva Castilla, Lima: Editores Técnicos Asociados.

LISSON CHÁVEZ, Emilio (1943): La Iglesia de España en el Perú, Sevilla: Editorial Católica Española (23 volúmenes).

MARTíN RUBIO, María del Carmen (2008): "El falso converso Paullo Topa”, en: La aventura de la historia, 10, 112; pp. 56-61.

MARTÍN RUBIO, María del Carmen (2007): "Evaluarán si restos hallados en iglesia de San Cristóbal pertenecen a Paullu Inca”. El Comercio, Lima, 11 de septiembre.

MENA, Cristóbal de (1968): La conquista del Perú llamada la Nueva Castilla. Lima: Editores Técnicos Asociados.

MILLONES, Luis (1984): “Taki Onkoy”, en: Cielo Abierto, X, 28; pp. 
RECOPILACIÓN de leyes de los reynos de Indias mandadas imprimir y publicar por Su Magestad Católica del Rey Don Carlos II Nuestro Señor. Madrid: Julián Paredes. Tomo I. 1681.

TOLEDO, Francisco de (1986): Disposiciones gubernativas para el virreinato del Perú 1569-1574. Sevilla: Escuela de Estudios Hispano-americanos, Consejo Superior de Investigaciones Científicas, Monte de Piedad Caja de Ahorros de Sevilla.

TRUJILLO MENA, Valentín (1981): La legislación eclesiástica en el virreinato del Perú durante el siglo XVI. Lima: Editorial Lumen.

ULLOA MOGOLLÓN, Juan de; HERNÁNDEZ TALAVERA, Diego; MEDEL DE LA FERIA, Hernando et alt. (1965): Relación de la provincia de los Collaguas para la discrepación de las Indias que su Majestad manda hacer. Indios de la Corona de Su Majestad. Jiménez de la Espada, Marcos. Relaciones geográficas de Indias, Tomo I, Madrid: Biblioteca de Autores Españoles, 1965 (326-333)

VARGAS UGARTE, S. J., Rubén (1965): Concilios limenses 1551-1772, Lima: Tipografía Peruana, T. 1.

VEGA, Antonio de (1948): Historia del Colegio y Universidad de san Ignacio de Loyola de la ciudad del Cuzco (Historia e narración de las cosas sucedidas en este Colegio del Cuzco destos Reynos del Perú, desde su fundación hasta hoy, primero de Noviembre, Día de Todos Santos año de 1600). Biblioteca Histórica Peruana Tomo VI. Lima: Instituto de Investigaciones Históricas. 